\title{
MANAGING THE ECONOMIES OF AFRICAN COUNTRIES DURING THE COVID-19 PANDEMIC - LESSONS FROM DEVELOPED COUNTRIES
}

Elias Igwebuilke Agbo

Department of Accounting and Finance,Faculty of Management and Social Sciences,

Godfrey Okoye University, Ugwuomu-Nike, Enugu, Nigeria.

E-mail: agboelias@ymail.com

Coronavirus has become a matter of great concern to global health organizations.It has posed major challenges particularly to health care systems in African countries due to the dearth of equipment, paucity of funding and insufficient training of healthcare workers. This has necessitated the introduction ofsomemitigation measures that involve lockdown,quarantine, social distancing and personal hygiene. In addition, surveillance and screening have remained, whenever possible, effective mechanisms of viral controlling the viral spread.The aftermath of these lockdown and social distancing measures has been collosal losses in production, supply, trades, investments, and employment. The monetary policy decisions and travel restrictions also severely affected the level of economic activities as well as the stock prices of major stock market variables. This paper explores the policy evolution of macroeconomic effects during the coronavirus pandemic with a view to ascertaining the means for mitigating the economic losses and macroeconomic uncertainty,. The study also aims at demonstrating the potential impact of fiscal, monetary, and macrofinancial policy measures on the economic losses caused by regulatory and quarantine measures.It suggests that in addition to continuing to search for an enduring cure of coronavirus, African countries should emulate the developed and other emerging market economies by implementing a comprehensive fiscal, monetary, and macro-financial policy to mitigate the pandemic's negative economic consequences.

Keywords:Coronavirus, GlobalCOVID-19 pandemic, Africa, quarantine, personal hygiene, social distancing,lockdown, economy.

\section{Introduction}

In the year 2019, anxiety had started to rise concerning the expected impact of both a USChina trade war, the US presidential elections and Brexit on the World Economy.This prompted the International Monetary Fund(IMF) to predict a moderate global growth of 3.4 percent.Amidst this global fear, the coronavirus desease(COVID-19) surfaced - an unprecedented pandemic that altered the global economic outlook unexpectedly.

Ozili and Arun(2020) report that the coronavirus pandemic has stifled economic activities in several ways. First, its spread encouraged social distancing which resulted to the shuting down of the financial markets, companies, businesses and events. Second, the speed at which the virus was spreading and the heightened fear and uncertainty cocerning how bad the situation could become resulted in the flight to safety in consumption and investment among consumers, investors and trade partners across the Globe.According to BIS (2019), this was happening when,financially, public firms were sitting on a considerable amount of corporate debt that piled up in recent years 
Baldwin and Weder di Mauro (2020a, 2020b) report that epidemiologists, economists, and policymakers persistently devoted considerable attention to forecasting the human ravages and economic toll of COVID-19.Also, as a result of fear and uncertainty as well as the prediction that the profits of companies werelikely to be reduced because of the effect of COVID-19, the stock markets across the univers lost about US\$6 trillion in wealth in one week from 24th to 28th of February(Ozili and Arun(2020), Ozili and Arun report that the S\&P 500 index lost over $\$ 5$ trillion in value in that same week in the US just as the S\&P 500's largest 10 companies incurred a combined loss of over $\$ 1.4$ trillion.A part of the loss in value arose from the speculation by investors that firms' profits would go down as a result of the impact of Covid-19.According to the International Air Transportation Association (IATA)mentioned inOzili and Arun(2020), the air travel industry forcasted that it would lose US\$113 billion if the COVID-19 outbreak was not quickly contained.For the IMF, it was reported to have downgraded its growth projection for the global economy as the COVID-19 outbreak threw its earlier projection into serious doubt. The pandemic also affected the tourism industry as the travel opportunities for Chinese tourists that usually spend a lot of money annually, were severely reduced. Flight cancellations increased; hotel bookings and local and international events worth over \$200billion were cancelled(Ozili \& Arun,2020).Manycountries such as Iran, Italy and France issued stay-at-home nationwide policies to bring the spread of the virus under control. The national public healthcare infrastructure was put under serious pressure as a result of multiple deaths caused by the virus. The stay-at-home policies planted the seeds of recession particularly in Africa and other developing nations.Consequently, according toFinancial Times(2020) cited in Ozili and Arun(2020), economists generaly agreed that the coronavirus pandemic would plunge the world into a global recession. Georgieva (2020)cites the International Monetary Fund as predicting in March 2020 that there would be a global recession expected to be at least as bad as the 2007-8 global financial crisis. In spite of the fact that recession is not new in the economic history of nations universally(seeStiglitz, 2010; Gaiotti, 2013; Bezemer, 2011; Mian \& Sufi, 2010; Bentolila et al, 2018; Bagliano \& Morana, 2012 cited in Ozili \& Arun,2020), the cause of the 2020 global recession is regarded as a novelty in modern history.According to Ozili and Arun, the coronavirus introduced a new type of recession which was different from the past originators.

In this paper, the manner in which the coronavirus outbreak led to spillovers into major sectors of the global economy is shown.The paper also demonstrates how fast policy response by several governments either triggered and prolonged the recession while trying to save the lives of citizens. The effect of social distancing policies on the level of economic activities and stock index prices is also highlighted. The study contributes to the literature by showing that non-financial factors or non-economic factors can bring about both a financial and economic meltdown in significant ways.

The rest of the paper is structured in the following way. Section 2 provides the review of the related literature. Section 3 discusses the global spillover of corona viruspandemic.Section 4 discusses its impact in Africa. Section5 highlights the anticipated aftermaths of the the pandemic.Section 6 highlights the recommended approaches towards containing the economic effects of COVID-19 pandemic while section7 concludes the paper.

\section{Review of the related Literature}

\subsection{Conceptual framework}

\subsubsection{Concept ofcoronavirus}

Cennimo(2020) definesCOVID-19 as an illness caused by a novel coronavirus.It is a severe acute respiratory syndrome coronavirus 2 (SARS-CoV-2) which was formerly called 2019$\mathrm{nCoV}$.The desease was first identified amid an outbreak of respiratory illness cases in Wuhan 
City, Hubei Province, China.COVID-19 was initially reported to the World Health Organisation(WHO) on December 31, 2019. On January 30, 2020, the WHO declared the COVID-19 outbreak a global health emergency.On March 11, 2020, the WHO declared COVID-19 was declared a global pandemic by the World Health Organization(WHO).This was its first time of its being so designated since declaring H1N1 influenza a pandemic in 2009.

The WHO refered to the Illness caused by SARS-CoV-2 as COVID-19, a acronym derived from coronavirus disease 2019. According to Cennimo(2020), the name was chosen to avoid stigmatizing the virus's origins in terms of populations, geography, or animal associations.On February 11, 2020, the Coronavirus Study Group of the International Committee on Taxonomy of Viruses issued a statement announcing an official designation for the novel virus as severe acute respiratory syndrome coronavirus 2 (SARS-CoV-2).

\subsubsection{Treatment}

According to Cennimo(2020), on May 1,2020,the authorization for the emergency use of the antiviral drug remdesivir took place. This authorization aruse from some preliminary data showing a faster time to recovery of hospitalized patients with severe coronavirus disease.Several other antiviral agents, immunotherapies, and vaccines have continued to be investigated and developed as potential therapies.

\subsection{Theoretical framework}

\subsubsection{The Ellsberg Paradox}

The Ellsberg paradox is a paradox in decision theory in which people's choices donot go in accordance with the postulates of subjectively expected utility. It is generally taken to be an evidence for ambiguity. Although a version of it was noted considerably earlier by Keynes(1921), the paradox was popularized by Ellsberg(1961), The basic idea is that people overwhelmingly prefer taking on risk in situations where they know specific odds rather than an alternative risk scenario in which the odds are completely ambiguous. They will always choose a known probability of winning over an unknown probability of winning even if the known probability is low and the unknown probability could be a guarantee of winning.

The Ellsberg Paradox shows that individuals have an aversion to uncertainty that goes beyond their aversion to risk.According to Reddy(2020), in a situation where both the "state space" describing possible events and the probability to be attached to each such event are unknown, the emotional element in decision-making is usually prominent.Panic is itself a risk factor and can be triggered by the wrong public actions or calmed by the right ones.

\subsubsection{Fundamental Uncertainty}

Keynes (1921) and Knight (1921) are considered as the inventors of the concept of fundamental uncertainty in economics. According to the two authors, a distinction ought to be made between risk and uncertainty. In the case of risk, all possible future events or consequences of an action or decision are known.For uncertainty, this is not the case.

Dow(n.d), considers uncertainty as being interdependent with the evolution of institutions and behavior, including that designed to help society cope with uncertainty. While some mainstream theory addresses uncertainty, it employs a much narrower concept than fundamental uncertainty. The author asserts that while ignoring uncertainty can at times be a successful coping mechanism,people maitain that ignoring uncertainty seriously limits the realism of theory and therefore also practice and policy. 


\subsubsection{Coronavirus conspiracy theories}

The coronavirus pandemic has brought about the spread of several conspiracy theories about the virus.According to Hadden(2020), nearly one third of Americans believe in coronavirus conspiracy theories. Conspiracy theories thrive in a crisis. They appear to be psychologically comforting and seem to provide an explanation that allows people to preserve their own beliefs in uncertain times. People tend to turn to conspiracy theories when they feel powerless.

Epidemics generate conspiracy theories. Generally, these theories all tend to have the same basic structure.It is usual for someone very powerful to mke up their mind to use a disease to influence or injure the public in order to achieve some specific goals(Hadden,2020). Many important conspiracy theories in recent times have been about disease, and some of these conspiracy theories have the ability to threaten public health, e.g. by discouraging people from following the advice and recommendations of health authorities. The topten among such theories as enlisted by Lynas(2020). are as follows:- (i) Coronavirus was caused by 5G (ii) Bill Gates is responsible forfor the virus (iii) The coronavirus virus escaped from a Chinese lab(iv)Insinuation that COVID was created as a biological weapon(v) The US military is the importer of COVID into China (vi) GMOs are somehow to blame for the virus (vii) COVID-19 doesn't actually exist (viii) The pandemic is being manipulated by the 'deep state' (ix) COVID is a plot by Big Pharma(x) The COVID death rates are inflated. Against each of those conspiracy theories Lynas(2020) raised some arguments to debunk each of those alligations .

The study goes further to advise one to always speak out and combat online misinformation and conspiracist narratives, whether on COVID or climate change or anything else.

According to Lynas(2020), conspiracy theories are a normal part of how humans understand reality.

\subsection{Empirical review}

Ozili and Arun(2020) studied the impact of COVID-19 on the Global Economy from the period from the start of 2020 through March when the coronavirus began spreading into other countries and markets. The aim of the study was to find out how a health crisis translate to an economic crisis and why the spread of the coronavirus brought the global economy to its knees.The study on real-world observations in assessing the restrictive measures, monetary policy measures, fiscal policy measures and the public health measures that were adopted during the period. It empirically examined the impact of social distancing policies on economic activities and stock market indices. The findings show that the increasing number of lockdown days, monetary policy decisions and international travel restrictions severely affected the level of economic activities and the closing, opening, lowest and highest stock price of major stock market indices.

Ma, Sili and Zhou(2020) also studied the impact of COVID-19 as they considered its forecasting and progress central in the planning of policymakers around the world.The result of the study shows that GDP growth contractions were immediate and sizeable.However, it varied from country to country.. The negative effect on GDP was observed to have responded less in countries with larger first-year responses in government spending and the indirect effects on GDP growth from affected trading partners were also significant.

In a related study,De Vito and Gomez( 2020) sought to determine how long it may take for some listed firms to become cash constrained, and what kind of interventions would be most effective among listed firms. . It used the financial statements of 14,293 listed firms from 26 countries for the year 2018 to answer some questions Three distress scenarios; with low, moderate and high risk denoting drops in sales of $25 \%, 50 \%$, and $75 \%$ respectively, relative 
to the base-case or the observed scenario. The authors performed stress tests of two liquidity ratios under the assumption that operating costs and the balance sheet remained as of 2018 for each firm. According to them, the first ratio, the 'cash burn rate', measured the number of years a firm was able to finance its operating costs without any further cash contribution from creditors or shareholders. The second ratio, the 'cash flow to debt ratio', was interpreted as the percentage of current liabilities (including short-term debt) covered by the annual cash flows from operations. The study found that the coronavirus pandemic had endangered the liquidity position of not only SME firms, but also large listed firmsThe analysis by country disclosed the following results(i) While focusing on the moderate liquidity risk scenario with $50 \%$ drop in annual sales, about $22 \%$ of firms in each country in the sample would, on average, become cash constrained within six months. (ii)Four (five) countries would have a percentage of illiquid firms one-standard deviation above (below) the mean.(iii) In the highrisk scenario, the same exercise yielded three (six) countries one standard deviation above (below) the mean percentage of illiquid firms (40\%).(iv) The number of illiquid firms in China, Greece, Italy, and Spain was below the mean in both scenarios. The study also studied the policy implications of two alternative policies: tax deferrals and a direct provision of cash to firms as a lump sum similar to a 'bridge loan' granted by the government. The results of the study also show that tax deferrals decrease the operating costs, while a direct provision of cash to firms as a lump sum increases the firm's cash reserves. Some of the other related studies cited in Ozili and Arun(2020),such asEl-Erian (2020), Larry Elliot (2020), Horowit (2020) equally found the impact of coronavirus on the global economy as highly devastating.

\section{The global spillover of corona virus}

According to Baldwin and Weder di Mauro(2020a),the impact of COVID - 19 has been tremendous.It has impacted several sectors all over the universe negatively. The authors smmerized their observations on how the pandemic has ravaged the various sectors as follows:-.

\section{a. Health crisis severity}

Even though the COVID-19 crisis stands out for its severity, other episodes were equally large. For instance, 500,000 infections were estimated to have occurred in Hong Kong in the first two weeks of the 1968 Flu.

Average GDP growth for the non-disease sample was 3.83\%. For affected countries, the average is $1.44 \%$ in the year they started, and $3.98 \%$ in the year after. Countries have different experiences.During the episodes, economic growth in China continued practically unhindered. Finland and the US were essentially on top of each other in non-Crisis years and in bounce-back years, but a gap opened between them during crisis years.

\section{b.Effect on high-income and low-income countries}

The high-income countries affected by the crisis had a GDP growth rate in the onset year that was 3\% less than the GDP growth for high-income countries unaffected by the crises. However,the bounce-back for those affected high-income countries was quick, as evidenced by the fact that growth was nearly $1 \%$ higher in affected countries in the year after the crisis was declared. The affected low-income countries had GDP growth rates that were not significantly different from unaffected low-income countries. 


\section{c.Fiscal policy works, especially government expenditures on health}

In response to COVID-19, finance ministries engaged in a variety of spending and taxrelated policies designed to support households and businesses, with the hope of softening the effect of the crisis on economic activity.

\section{d.International trade elements}

Baldwin and Weder di Mauro(2020a) also considered the international trade aspects of past health crisis episodes. First, they estimated the impact of the crises on the growth rate of international trade, measured as each country's multilateral exports plus imports. They used the same local projections estimator. International trade dropped, falling to a level that was on par with the US trade collapse in 2008-09 (Levchenko,Lewis, \& Tesar,2010;Baldwin 2020), but rebounded quickly.Indirect effects were not trivial as it contributed around $-0.3 \%$ to GDP growth in the onset year (as against direct effects of $-2.1 \%$ ), and $+0.4 \%$ in the bounce-back year.Many policymakers showed eagerness to 're-open the economy'. However, a restoration of robust international trade linkages was yet to receive support .The signs of a backlash against China had already appeared from policymakers and in the media. Countries were building up sentiment not to be very reliant on imports, especially in sensitive sectors like medical supplies.

\section{e. Effect of the coronavirus on global oil prices}

According toBlackmore(2020), since Dcenber31, the spread of the COVID-19 had sent global stock markets falling doubling down on a pessimistic oil demand outlook in spite of numerous short-term risks to supply. The author forecasts that, as the coronavirus spreadbeyond Asia, the oil market wouldcontinue to suffer losses. Coronavirus is said to have affected the oil market in two ways. First, restriction in travel in an effort to coneain the virus limited the use of jet fuel, and supply chains slow and industrial activity declines as companies sent workers home.This implies less oil and oil-based products were used and produced.. Second, the stock market reaction to the effect of the coronavirus on the global economy created a projection of global oil demand over the long-term. With the broader market sentiment about the health of the global economy declining, the projections about the future oil demand curve would also decline. This prompted flight away from oil and energy stocks and further drew down prices.

\subsection{Global update of corona vius cases and deaths as of June 24, 2020}

According to the European Centre for Disease Prevention and Control(2020), from 31 December 2019 to 24 June 2020, 9229049 cases of COVID-19 (in accordance with the applied case definitions and testing strategies in the affected countries) were reported.The toal number of reported deaths was 477269 .

\section{The following cases were reported continent by continent:-}

Africa: 324392 cases; the five countries that reported most cases were South Africa (106 108), Egypt (58 141), Nigeria (21 371), Ghana (14 568) and Algeria (12 076).

Asia: 1949967 cases; the five countries that reported the highest number of cases were India (456 183), Iran (209 970), Turkey (190 165), Pakistan (188 926) and Saudi Arabia (164 144).

America: 4610824 cases; the five countries with the highest number of cases were were United States (2 347 022), Brazil (1 145 906), Peru (260 810), Chile (250 767) and Mexico (191 410). 
Europe: 2334148 cases; the five countries witk the highest number of cases as reported were Russia (599 705), United Kingdom (306 210), Spain (246 752), Italy (238 833) and Germany (191 449).

Oceania: 9022 cases; the five countries that had the highest numberof cases were Australia (7 492), New Zealand (1 166), Guam (226), French Polynesia (60) and Northern Mariana Islands (30).

Other: 696 cases were reported from an international conveyance in Japan.

\section{The reported deaths were recorded as follows:-}

Africa: 8613 deaths; the five countries that reported most deaths are Egypt (2 365), South Africa (2 102), Algeria (861), Sudan (548) and Nigeria (533).

Asia: 49537 deaths; the five countries with the highest number of deaths were India (14 476), Iran (9 863), Turkey (5 001), China (4 640) and Pakistan (3 755).

America: 230079 deaths; the five countries that reported the highest number of deaths were United States (121 228), Brazil (52 645), Mexico (23 377), Canada (8 454) and Peru (8 404).

Europe: 188902 deaths; the five countries with the biggest roster of deaths were United Kingdom (42 927), Italy (34 675), France (29 720), Spain (28 325) and Belgium (9 713).

Oceania: 131 deaths; the 4 countries which reported the mighest number of deaths were Australia (102), New Zealand (22), Guam (5) and Northern Mariana Islands (2).

Other: 7 deaths weres reported from an international conveyance in Japan.

\subsection{Coronavirus Policy Response Issues}

Ozili and Arun(2020) hghlighted the issues arising from corona virus policy response by the affected countries as follows:-

(i) Deciding on which one to save first - the people or the economy.

Policy makers in government and Central banks were faced with a major decision on whether to save people first before the economy or vice versa. One choice had to be made at a time because it was difficult to achieve both at the same time. During the outbreak government would have to tell the citizens to stay at home in order to control the spread of coronavirus which means economic activities will have to stop or reduce significantly. This policy would trigger an economic slowdown. According to Ozili and Arun(2020), policy makers in many countries felt it was better to save thepeople before saving the economy.Conesquently, the economy was allowed to suffer in some

countries.

(ii) Contradictory and conflicting policy response During the coronavirus pandemic, many of the fast policy responses were insufficient, even thoughthose policies were formulated with good intentions. For instance,monetary policy helped to calm financial markets.However, it failed to stop the recession. Also, Central banks responded to the coronavirus outbreak by modifying their monetary policy variables such as lowering interest rates and increasing money (or credit) supply to crucial sectors of the economy. Despite these efforts, monetary policy alone could not shore up demand when there was a general flight to safety among consumers and investors.

The expansionary monetary policies adopted in many countries during the outbreak reallyencouraged economic activities.However,the economic agentscould not engage in economic activities as governments had imposed social distancing restrictions in the face of the fear of contacting the coronavirus during the outbreak.Even the efforts of the central bankers to shift the focus in thatdirection could not achieve all that much. 
(iii) Using broad fiscal expenditure and sector priority

Some countries employed a broad federal fiscal bail-out package to minimize the harsh effects ofcoronavirus on the economy during the outbreak. Finding out which sectors would receive part of the stimulus package and which sectors would not receive the stimulus package became a politicalissue in some countries like theUnited Kingdom and United States. It stirred up debates as to whether the public authorities considered the entertainment sector, hospitality sector and the circular economy to be less important and insignificant to the economy and ineligible to receive some financial assistance from the federal stimulus package as against other sectors which were considered to be significant contributors to the economy. Some members of the excluded sectors protested as they felt that the government did not consider their sectors as significant contributors to the economy.

(iv) Fast policy destroyed some segment of the hospitality industry very fast.

The policies such as the 'stay-at-home policy' and the 'social distancing policy' seriouslyharmed the incomes of restaurants, pubs, shops and hotels in many locations. In some cases,this resulted in closing them down. The 'stay-at-home policy' and the 'social distancing policy' policies destroyed many businesses in the hospitality industry in such manners that were neveranticipated. The government did not take responsibility for the failure of small and largebusinesses that did not survive the coronavirus outbreak as a result of the government-imposed social distancing policy and lockdown restrictions. Some people reasoned that itis either the social distancing policy wasimplemented too early or the policy was taken to the extreme by citizens and travellers who were afraid of patronizing such businesses for fear of contacting the COVID-19 disease(Ozili \& Arun,2020).

\section{The impact of Covid-19 in Africa.}

Universally, the COVID-19 coronavirus pandemic hasconstituted a health crisis which has not been experienced the in modern era. Apart from the daunting cost that this emergency situation poses in terms of the heavy loss of human lives and social upheaval, the enonmic impact of the COVID-19 coronavirus pandemic is seriously dramatic. Many governments have had to impose a lockdown of business and citizens for an undetermined period. As a result, supply has been disrupted in several industries, demand has plummeted overnight, and many lost their jobs, both across countries and sectors (Baldwin 2020). This situation has increased the prospects of a global economic recession (OECD 2020).

The COVID-19 or coronavirus pandemic which has affected the global economy has also affected the African economy through spillovers to African countries. Many African countries have taken bold quarantine and lockdown measures to control the spread of COVID-19, although this has come at a cost such as the collapse of health systems and a painful economic crisis or recession.

According to Selassie(2020), thepredicted that Africa's economy would contract by 1.5 percentage points in 2020.Selassie observed that this means a loss of about \$200bn (£163.5bn) in income forAfrica

The outcome of a survey carried out by Moulds(2020) shows thatAfrica's swift action to contain COVID-19 had been effective in suppressing the coronavirus transmission so far.Also, the reults of the survey revealed as follows:-(i)There was broad support for stay-athome orders, but this could weaken easily;(ii) $69 \%$ of survey respondents said getting enough food and water would be difficult if they had to stay home for 14 days;(iii)Two-thirds of people in 20 African countries entertained the fearof going hungry if they had to quarantine for 2 weeks, (iv)Confirmed cases of COVID-19 in Africa remained comparatively low, at 51,000 as of 6 May. However, those numbers were growing fast. 
Moulds(2020) claims that after conducting a survey, the Partnership for Evidence Based Response to COVID-19 (PERC) reported some worrying findings about the impact of coronavirus on the lives of many Africans.

Part of that report was that half of respondents to the survey, carried out in 28 African cities, said they would run out of money if they had to stay in-doors for 14 days.Secondly, the lowest-income households expected to run out of food and money in less than a week. In Nigeria and Kenya, social media users admitted that hunger had forced them to violate stayat-home orders in order to look for food.In addition,the survey report disclosed that almost $60 \%$ of people responding to the survey said they did not have the space at home to isolate sick people and the majority of people did not have space to isolate family members.

\subsection{Response to coronavirus by African governments}

According to Moulds(2020), the governments across Africa responded quickly to the coronavirus pandemic with public health measures so as to prevent the spread of the virus.For instance, South Africa declared a national state of disaster and implemented a nationwide lockdown before reporting its first death from COVID-19.For Uganda, there was a suspension of public gatherings before the first documented case in the country. Nigeria started screening passengers at international airports nearly one month before the first case was detected.All these actions gave African countries an advantage in limiting the spread of the virus.

\subsection{The Contribution of the World Economic Forum in containing the coronavirus outbreak}

The World Economic Forum, which is the International Organization for Public-Private Cooperation, has at the centre of its mission securing cooperation among governments, international organizations and the business community to ensure quick global response to the COVID-19 pandemic.

Since its launch on 11 March, the Forum's COVID Action Platform has brought together 1,667 stakeholders from 1,106 businesses and organizations to mitigate the risk and impact of the global health emergency(COVD-19).

The platform is said to have been created with the support of the World Health Organization and is open to all businesses and industry groups, as well as other stakeholders, aiming to integrate and inform joint action.As an organization, the Forum has a track record of supporting efforts to contain such epidemics.

\subsection{Resources Constraint}

The report of the PERC cited in Moulds(2020) shows that healthcare systems in many African countries were ill prepared for a pandemic, with low numbers of healthcare workers and little capacity for providing critical care to the severely ill(Moulds,2020). Low and middle-income countries, including those in Africa, had limited resources to mitigate the social and economic disruption caused by the COVID-19.

\subsection{Fragile support for public health measures}

PERC's survey found that people in the 20 African countries currently supported private health support measures. However,the consensus inthat direction may be weak. A large share of the population feard that a prolonged quarantine would result in food insecurity and grave financial hardships. 
4.4 Mitigating the effect of coronavirus on African countries

Accoding to Ahmed(2020), in the face of the emergenceof COVID-19 in low-income countries, African inclusive, community mitigation might delay the influenza peak to decrease stress on the health-care system; comsequently, that would decrease morbidity and mortality. Social distancing and hygienic practices are among the main community mitigation measures that health institutions recommended during the influenzapandemics.Ahmed(2020) reports that there was the insistence that people separated themselves from others and regularly washed their hands, avoided touching their face, covered their mouths and noses when coughing or sneezing, and cleaned frequently touched surfaces. In the situation where the low- income countries lacked funding, the public health measures relied on preventive actions such as social distancing and hygienic practices to mitigate the spread of the coronavirus

Also, surveillance, accurate screening, and vaccination remained, whenever possible, effective mechanisms for cotrolling the virus.

\section{The economic aftermath of the the COVID-19 pandemic}

According to Baldwin and Weder di Mauro(2020a), the effects of COVID-19 globally are highly likely to be higher than those of the previous episodes of health crisis. Since COVID19 is more widespread than the average crisis in the past,. It might turn out to have a higher mortality rate as well. For instance, the existing global travel bans, social distancing, and economic lockdowns as well as value chains in production are also more prevalent than was the case in the past.This situation suggests that countries will go down (and perhaps rebound) more sharply than was the case in the past. Base on the initial data releases, GDP growth in 2020Q1 in China, the US, and euro area were $-6.8 \%,-4.8 \%$, and $-14.5 \%$, respectively, while US unemployment was $14.7 \%$ in April 2020(Baldwin and Weder di Mauro(2020a). These early signs suggest that COVID-19 would be worse than the earrlier pandemics. Nevertheless, massive interventions on the part of central banks and fiscal policymakers are now being undertaken worldwide. According to CNN Business(2020) cited in Ayittey, Ayittey, Nyasha, Chiwero,Kamasah \& Dzuvor (2020), some capital economists estimate that, without urgent global actions to curtail the Wuhan 2019-nCoV within the shortest possible time, China is expected to lose up to $\$ 62$ billion in the first quarter of the year, while the world is likely to lose over $\$ 280$ billion within the same period. This forecast compares closely to the World Banks estimation that even a weaker flu pandemic, such as the 2009 H1N1 viruses, could still wipe $0.5 \%$ off global GDP, which amounts to approximately $\$ 300$ billion.

According to CNN Business(2020) cited in Ayittey, Ayittey, Nyasha, Chiwero,Kamasah \& Dzuvor (2020),some capital economists estimate that, without urgent global actions to curtail the Wuhan 2019-nCoV within the shortest possible time, China is expected to lose up to $\$ 62$ billionin the first quarter of the year, while the world is likely to lose over $\$ 280$ billion within the same period.This forecast compares closely to the World Banks estimation that even a weaker flu pandemic, such as the $2009 \mathrm{H} 1 \mathrm{~N} 1$ viruses, could still wipe $0.5 \%$ off global GDP, which amounts to approximately $\$ 300$ billion.

Uncertainties over the Wuhan 2019 Novel Coronavirus (2019-nCoV), which has killed at least 1,775 people and made more than

70,000 to become sick as of February 17,2020 had as at 24 June 2020, progressed to9 229049 cases of COVID-19 and 477 269deaths. It has interrupted the global trade and supply chains, depressed asset prices and forced multinational businesses to make hard decisions with limited information. 
Accoding to Ayittey, Ayittey, Nyasha, Chiwero,Kamasah and Dzuvor (2020), when the loss of commerce, trade, tourism, and major impacts on global supply chains are taken into consideration, the economic impacts of the outbreak will be much both within China and globally. A market diagnosis completed by Bloomberg economists, concludes that China's first-quarter GDP growth may slip to $4.5 \%$ year-on-year.The means losses to different countries across the world. Theglobal GDP is likely to decline by roughly $0.42 \%$ in first quarter of the year due to the outbreak.

\section{Recommendations}

This study recommends as follows:-

(i) Public funds should be provided to improve the capacity of health systems in developing countries.

(ii) Financial support should be provided to individuals, entrepreneurs and corporations to help them cope with the adverse effect of the coronavirus crisis.

(iii) Employers should be granted incentives to preserve employment during the crisis to avoid mass layoff of workers.

(iv) Central banks should provide liquidity and credit support as well as asset purchase programs to prevent credit and liquidity crunch in domestic financial markets.

(v) Countries should not only address emergencies, but also include policies aimed at expanding productive capacities, promoting economic diversification and upgrading technology, while ensuring social and environmental protection. For that to become a reality, however,there ie the need for global coordination(Cantore,Hartwich,Lavopa,, Haverkamp,K., Laplane and Rodousakis,N.(2020).

(vi)There is the need for an orderly debt-restructuring plan to hasten economic recovery in the aftermath of the health crisis(Becker, Hege, \& Mella Barral, 2020; Bénassy-Quéré et al,2020).

(vii) Governments should intervene to mitigate the drop in business activity and employment and to prevent massive bankruptcies (Baldwin \& Mauro 2020). Governments have to support businesses and workers who are losing income-or risk dangerous knock-on effects on banks and the real economy - and find a way to finance these expenditures.

(viii) According to De Vito and Gomez (2020), the US Federal Reserve is relaunching the Commercial Paper Funding Facility (CPFF), created during the Great Recession, to purchase commercial paper and short-term, unsecured loans obtained by businesses for everyday expenses and the US corporations are allowed to delay taxes up to some extra period.It also extends some state loans and guarantees to small- and medium-sized firms as well as firms in specific sectors that were particularly affected by the crisis, like cargo and passenger airlines. Similar measures are also adopted at various scales by many other governments around the world in an attempt to provide firms with the liquidity that banks and capital markets may not be facilitating during the corona pandemic.This paper suggeststhat all affected countries should borrow a leaf from these developed nations. 
(ix)There is also an urgent need to ramp up the production of essential commodities such as ventilators, gloves, and masks; to provide hospital beds ensure that required personnel can themselves turn up for work.(Reddy,2020).

(x) In response to the pandemic, public policy needs to focus on providing an anchor and assurance to private actors.

(xi) Governments should provide some backstop that ensures the survival of firms and the continuity of employment and incomes so as to maintain aggregate demand and broad-based solvency and liquidity.

In African countries particularly,the following measures are additionally recommended:-

(i) While caseloads remain low, they should build public health capacity to test, trace, isolate and treat cases.These are the necessary foundation for reopening society.

(ii)Data should be monitored on how public health and social measures (PHSMs) meet local COVID-19 conditions and needs. The countries should also monitor data so as to determine when and how to lift them in such a manner that would balance lives and livelihoods.

(iii) Communities should be engaged to adapt PHSMs to the local context and effectively communicate about risk to sustain public support, achieve widespread adherence, and protect vulnerable populations.

\section{Conclusion}

COVID-19 has become an increasing concern to global health organizations and posed major challenges to health care systems. In African countries, the sitaution remains worse due to the absence of equipment, lack of funding and insufficient training of healthcare workers. Consequently, some mitigation measures that involved social distancing and personal hygiene had to be prioritizedby their governments. In addition, whenever possible, surveillance, accurate screening, and vaccination remained, effective means of viral control.The lockdown and social distancing measures triggered losses in production, supply, trades, investments, and employment. The confirmed cases of infection and death continued to be on the increase. The monetary policy decisions and travel restrictions severely affected the level of economic activities as well as the stock prices of major stock market indices. In orderto halt the economic losses and macroeconomic uncertainty, this paper surveyed the policy evolution of macroeconomic effects during the COVID-19 pandemic. It demonstrated the potential impact of fiscal, monetary, and macro-financial policy measures on the economic losses caused by regulatory and quarantine measures. The study reveals that, with regard to financial stability, future stress testing of the resilience of the financial system should take into account human health factors as an important item in their stress testing activitiess. Among others, it recommends that African countries should join the abvanced and other emerging market economies to implement a comprehensive fast-track fiscal, monetary, and macro-financial policy to counteract the pandemic's negative economic consequences.

\section{References}

1. Ahmed,O.B.(2020).Mitigating the spread of COVID-19 in low-income countries, 15(2), 41-44, April-June, 2020DOI: 10.5897/SRE2020.6677 Scientific research and essays ISSN 1992-2248 at: https://www.researchgate.net/publication/342097167.

2. Allen, F., \& Carletti, E. (2010). An overview of the crisis: Causes, consequences, and solutions. International Review of Finance, 10(1), 1-26. 
3. Available from:

https://www.researchgate.net/publication/ 340236487_Spillover_of_COVID-19_impact_on_the_Global_Economy [accessed Jun 11 2020].

4. Ayittey,F.K.,Dzuvor,C.,Nyasha B. Chiwero,N.B.\& Habib,A. (2020)Updates on Wuhan 2019 Novel Coronavirus Epidemic.Journal of Medical Virology 'DOI: 10.1002/jmv.25695https://www.researchgate.net/publication/339030303

5. Baldwin, R \& Weder di Mauro,B. (2020), Mitigating the COVID economic crisis: Act fast and do whatever it takes.CEPR Press VoxEU.org, 18 March.

6. Baldwin, R (2020), The Greater trade collapse of 2020: Learnings from the 2008-09 Great Trade Collapse, VoxEU.org, 07 April.

7. Becker,B., Hege,U.\& Mella Barral,P.(2020).Keepingthe lights on :Economic medicine for a medical shock", VoxEU.org, 21 March.

8. Bénassy-Quéré, A., Marimon,R., Pisani-Ferry,J., Reichlin,L., Schoenmaker,D. \& BWeder di Mauro,B. (2020),Europe needs a catastrophe relief VoxEU.org, 10 March.

9. Bentolila, S., Jansen, M., \& Jiménez, G. (2018). When credit dries up: Job losses in the great recession. Journal of the European Economic Association, 16(3), 650-695.

10. Bezemer, D. J. (2011). The credit crisis and recession as a paradigm test. Journal of Economic Issues, 45(1), 1-18.

11. BIS (2019), Annual Economic Report, Bank for International Settlements.

12. Blackmore,R.(2020).Coronavirus and the oil market: The effects thus far and what to expect next.Retrieved from nexhttps://www.atlanticcouncil.org/blogs/newatlanticist/coronavirus-and-the-oil-market-the-effects-thus-far-and-what-to-expectnext/.March 3.

13. Cantore,N.,Hartwich,F.,Lavopa,A., Haverkamp,K.,Laplane,A \&. Rodousakis,N.(2020). Coronavirus: the economic impact. United Nations Industrial Development Organization. Retrieved from https://www.unido.org/stories/coronavirus-economic-impact.

14. Cennimo,D,(2020a). Coronavirus Disease 2019 (COVID-19) Medscape. https://emedicine.medscape.c

15. Cennimo,D.J.(2020b).Coronavirus Disease 2019 (COVID-19) Treatment and Management.Medscape.Retrieved from

16. Cohen J.(2020) Chinese Researchers Reveal Draft Genome of Virus Implicated in

17. De Vito,A. \& Gomez,J. ( 2020). COVID-19: Preventing a corporate cash crunch among listed firms. Working PaperMarch 29 Retrieved from https://voxeu.org/article/covid-19preventing-corporate-cash-crunch-among-listed-firms

18. El-Erian, M. (2020). The Coming Coronavirus Recession and the Uncharted Territory Beyond. Foreign Affairs, Media Report. Available at: https://www.foreignaffairs.com/articles/2020-03-17/coming-coronavirus-recession Financial Times (2020). Global recession already here, say top economists. Available at: https://www.ft.com/content/be732afe-6526-11ea-a6cd-df28cc3c6a68

19. Ellsberg, D. (1961). Risk, Ambiguity, and the Savage Axioms .Quarterly Journal of Economics. 75 (4): 643-669. doi:10.2307/1884324. JSTOR 1884324.

20. European Centre for Disease Prevention and Control(2020). COVID-19 situation update worldwide, as of 11 June 2020.Retrieved from https://www.ecdc.europa.eu/en/geographical-distribution-2019-ncov-cases.

21. Gaiotti, E. (2013). Credit availability and investment: Lessons from the "great recession". European Economic Review, 59, 212-227.

22. Georgieva, K (2020). IMF Managing Director Kristalina Georgieva's Statement Following a G20 Ministerial Call on the Coronavirus Emergency. IMF Press statement. Available at: https://www.imf.org/en/News/Articles/2020/03/23/pr2098-imf- 
managing-director-statement-following-a-g20-ministerial-call-on-the-coronavirusemergency

23. https://www.researchgate.net/publication/339209152

24. Hadden,J.(2020)

Corona

DOI: $10.1002 / j m v .25706$ theories.https://www.pulse.ng/bi/strategy/nearly-a-third-of-americans-believe-incoronavirus-conspiracy-theories-science/qp81gdlRetieved 25 April.

25. Horowit, J. (2020). The global coronavirus recession is beginning. CNN. Media report. Available at: https://edition.cnn.com/2020/03/16/economy/globalrecessioncoronavirus/index.htmlhttps://www.medscape.com/public/about

26. Jorda, O (2005). Estimation and inference of impulse responses by local projections, American Economic Review 95 (1): 161-182.Journal of Medical Virology. 2020. https://doi.org/10.1002/jmv.25685

27. Keynes,J.M. (1921). EconPort discussion of the paradox, 75-76, paragraph 315, footnote 2.

28. Kumer,S.P.(2020).COVIDCrisis:Fiscal,Monetary and Macro-financial Policy Responses. SSRN Electronic Journal

29. Larry Elliot, L. (2020). Prepare for the coronavirus global recession. The Guardian. Media report. Available at: https://www.theguardian.com/business/2020/mar/15/prepare-for-the-coronavirus-globalrecession

30. Levchenko, A A., Lewis,L.T \& Tesar,L.L (2010), The collapse of international trade during the 2008-09 crisis: in search of the smoking gun, IMF Economic Review 58: 214253.

31. Lynas,M.(2020). COVID: Top 10 current conspiracy theories. Retrieved fromhttps://allianceforscience.cornell.edu/blog/2020/04/covid-top-10-current-conspiracytheories. April 20,

32. Ma,C., Sili,R. \& Zhou,S. (May, 2020).Modern health crises: Recession and recovery.VOX CEPR Policy Portal

33. Mian, A., \& Sufi, A. (2010). The great recession: Lessons from microeconomic data. American Economic Review, 100(2), 51-56.

34. Moulds,J.(2020). How the threat of COVID-19 is affecting people across Africa.The World Economic Forum COVID Action Platform.May 24.

35. News/2020/01/chinese-researchersreveal-draft-genome-virusimplicated-wuhan-pneumoni a-outbreak

36. OECD (2020), OECD Economic Outlook, Interim Report March 2020, Paris: OECD Publishing.

37. Ozili,P.K \& Arun,T.G.(2020).Spillover of COVID-19: impact on the Global Economy

38. Reddy,S.G.(2020)Coronavirus and the Limits of Economics: Why standard economic theories have no answers for this kind of crisis.Retrieved from https://www.google.com/search?client=firefox-

$\mathrm{bd} \& \mathrm{q}=$ ECONOMIC+THEORIES++RELATED+TO+CORONAVIRUS+PANDEMIC.M $\operatorname{arch} 31$

39. Selassie,A.A.(2020). The impact of coronavirus on Africa's economy.British Broacsting Corporation.May 24.

40. Stiglitz, J. E. (2010). Interpreting the Causes of the Great Recession of 2008. Financial system and macroeconomic resilience: revisited. Bank for International Settlements. 